This is a pre-copyedited, author-produced version of an article accepted for publication in the Industrial Law Journal following peer review. The version of record (2019) 48 (3) Industrial Law Journal 377-415 is available online at: $\underline{\text { https://doi.org/10.1093/indlaw/dwv013 }}$

\title{
Interrogating the 'Dignity' Argument for Mandatory Retirement: An Undignified Development?
}

\begin{abstract}
Alysia Blackham*
Abstract: Human dignity is often cited as a justification and foundation for equality law. However, it is also used in some contexts to justify detracting from equal treatment, including in relation to mandatory retirement ages in the UK. Drawing on interdisciplinary scholarship from legal theory and industrial relations, this article argues case law on retirement ages adopts a limited approach to the notion of 'dignity', which is grounded in age stereotypes. It considers how a re-conceptualisation of 'dignity' might inform the future development of the law on retirement ages, and proposes alternative ways to secure individual dignity in employment that do not depend on mandatory retirement ages.
\end{abstract}




\section{INTRODUCTION}

Human dignity is often cited as a justification and foundation for equality law. Indeed, in countries such as Canada, South Africa and Germany, dignity is seen as the cornerstone and rationale for equality jurisprudence. ${ }^{1}$ These ideas have been integrated into the EU Charter of Fundamental Rights, which incorporates human dignity as an 'indivisible, universal' value, which is 'inviolable' (art 1), including in the area of work (art 31). Indeed, art 25 provides for the right of the elderly to 'lead a life of dignity and independence'.

While dignity might be a foundation of equality law, it is also used in some contexts to justify detracting from equal treatment. This is particularly evident in the case law around mandatory retirement. In the UK, employers may only adopt an employer-justified retirement age (EJRA) where it can be justified as a proportionate means of achieving a legitimate aim. In the seminal case of Seldon v Clarkson Wright \& Jakes, ${ }^{2}$ the UK Supreme Court identified two broad classes of legitimate aims that might be used to justify an EJRA: first, intergenerational fairness; and, second, dignity. ${ }^{3}$ While intergenerational fairness is being subjected to increasing academic

\footnotetext{
* Melbourne Law School, The University of Melbourne, email: alysia.blackham@unimelb.edu.au. The author is thankful to Prof. Colm O'Cinneide for his comments on an earlier version of this article.

${ }^{1}$ Sandra Fredman, Discrimination Law (Clarendon Law Series, 2nd edn, Oxford: Oxford University Press, 2011) 19-20. For discussion of the use of dignity in the Canadian context, see Aileen McColgan, Discrimination, Equality and the Law (Human Rights Law in Perspective 19, Oxford: Hart Publishing, 2014) 23-33.

${ }^{2}$ [2012] UKSC 16, [2012] 2 CMLR 50 ('Seldon').

${ }^{3}$ ibid [56]-[57].
} 
scrutiny, ${ }^{4}$ there has been limited consideration of the more controversial 'dignity' aim in the context of retirement ages, and how it relates to moral and legal theories of 'dignity' more broadly.

This article fills the existing lacuna in the literature, by considering both how the use of dignity in the case law on retirement ages differs from broader theoretical work; and how moral and legal theories of dignity might inform the future development of law in this area. Thus, this article has both descriptive and normative aims. In fulfilling these aims, I draw on interdisciplinary scholarship from legal theory and industrial relations, utilising several fields of knowledge to provide insights into a complex (legal) problem.

This article proceeds as follows. In Part 1, I provide an overview of how 'dignity' is developed as a concept in legal and moral theory, and how this relates to equality law. I argue that there are two potential conceptions of 'dignity': the first grounded in individual autonomy, and the second focused on social-respect. I argue that the definitional ambivalence around 'dignity' means it lacks a sufficient theoretical basis to act as the foundation for equality law. In the absence of a sound theoretical basis, courts should publicly declare and clarify the normative basis for legal decisions relying on the concept of dignity: otherwise, 'dignity' may merely become a cloak to allow judges to make (and disguise) difficult normative judgements.

\footnotetext{
${ }^{4}$ See Elaine Dewhurst, 'Intergenerational Balance, Mandatory Retirement and Age Discrimination in Europe: How Can the ECJ Better Support National Courts in Finding a Balance between the Generations?' (2013) 50 Common Market Law Review 1333.
} 
In Part 2, then, I interrogate the notion of 'dignity' as it is used in cases relating to retirement ages in the EU and UK. ${ }^{5}$ There is a clear message in the case law that older workers' dignity is likely best upheld through avoiding humiliating experiences, by removing individuals from employment at a fixed age. I argue that this reliance on 'dignity' as a legitimate aim to support compulsory retirement is grounded in numerous questionable assumptions, which are inconsistent with the empirical literature on ageing. Further, it adopts one limited interpretation of 'dignity' as social-respect, and ignores other contrasting approaches to how we might uphold dignity in this setting. The reliance on 'dignity' in this context can be used to reinforce traditional regimes and embed age stereotypes and norms in employment. Thus, the existing use of 'dignity' as a legitimate aim is normatively questionable, and may undermine the aims of age equality law. If dignity is to be retained as a legitimate aim, I argue for a view of dignity that accommodates arguments grounded in individual autonomy, while still accommodating social-respect.

In Part 3, I use these findings to reconsider the notion of 'dignity', and to normatively evaluate how the law should be developed in this area. I argue for a normative alternative to the use of retirement ages, through the use of a personalised approach to human resource management, and offer alternative ways to secure individual dignity in employment.

\footnotetext{
${ }^{5}$ While the UK 'Brexit' vote may challenge the simultaneous examination of EU and UK law in the future, in this article I proceed according to the current status quo, recognising the enduring influence of EU case law and Directives on the development of UK discrimination law.
} 


\section{DIGNITY}

Despite extensive academic musings regarding how we can (or should) conceive of human dignity, ${ }^{6}$ as a concept 'dignity' remains opaque, subjective, difficult to measure, malleable, and capable of being used for varying purposes. ${ }^{7}$ It is difficult to identify a consensus on the philosophical basis or origins of respect for dignity: Rosen traces the history of dignity in philosophical thought as being a progression from dignity as status, which is grounded in social position; ${ }^{8}$ to dignity as inherent value or worth; to dignity as behaviour, character, or bearing, which is an account of morally admirable behaviour. ${ }^{9}$ The influential Kantian notion of dignity as worth is rooted in the idea that every member of society deserves to be treated in a manner consistent with the high worth of the human species. ${ }^{10}$ This, then, assumes that (1) the dignity of the individual can be distinguished from the dignity of the species as a whole, (2) the dignity of all individuals is equal, ${ }^{11}$ and (3) no other species is 'equal to humanity'. ${ }^{12}$ For Kant,

${ }^{6}$ See, eg, Christopher McCrudden (ed), Understanding Human Dignity, vol 192 (Proceedings of the British Academy, Oxford: Oxford University Press, 2013); Marcus Düwell and others (eds), The Cambridge Handbook of Human Dignity: Interdisciplinary Perspectives (Cambridge: Cambridge University Press, 2014).

${ }^{7}$ Sandra Fredman, 'The Age of Equality' in Sandra Fredman and Sarah Spencer (eds), Age as an Equality Issue: Legal and Policy Perspectives (Oxford: Hart, 2003) 45.

${ }^{8}$ Jeremy Waldron and others, Dignity, Rank, and Rights (The Berkeley Tanner Lectures, Oxford: Oxford University Press, 2012).

${ }^{9}$ Michael Rosen, Dignity: Its History and Meaning (Cambridge: Harvard University Press, 2012) 54 57.

${ }^{10}$ George Kateb, Human Dignity (Cambridge: Belknap Press of Harvard University Press, 2011) 3-4.

${ }^{11}$ ibid 5.

12 ibid 6. 
human dignity is derived from the 'incomparable' value of the species derived from our morality. ${ }^{13}$

Moving beyond the theoretical basis for upholding human dignity, there is also limited consensus regarding what is required to achieve dignity in practice. That said, there are two (very broad) schools of thought on this topic, where the notion of dignity has been developed to some extent. For the first group of scholars, dignity is seen as requiring autonomy, choice and individual freedom. For Dworkin, dignity entails the freedom to make life-altering choices. Dignity requires equality: governments must both treat people with equal concern, as human beings capable of suffering and frustration; and equal respect, as being capable of forming and acting on intelligent conceptions of how their lives should be lived. ${ }^{14}$ In Dworkin's view, then, dignity is inextricably linked to individual choice, which can be facilitated (with minimal intervention) by equal treatment by government. This is consistent with Raz's view of dignity, which sees dignity as requiring respect for autonomy, and having an individual right to control the future. ${ }^{15} \mathrm{O}$ 'Neill interprets Kantian dignity as treating individuals in ways to which they can rationally consent: we need to consent to be treated as persons. ${ }^{16}$ Réaume also interprets dignity as being about choice, and giving individuals

\footnotetext{
${ }^{13}$ For a detailed account, see Oliver Sensen, Kant on Human Dignity (Kantstudien. Ergänzungshefte, Berlin: De Gruyter, 2011). However, later authors see these assumptions as grounded in existential not moral thought: Kateb (n 10) 10.

${ }^{14}$ Ronald Dworkin, Taking Rights Seriously (London: Duckworth, 1977) 272.

${ }^{15}$ Joseph Raz, The Authority of Law: Essays on Law and Morality (2nd ed, Oxford: Oxford University Press, 2009) 221.

${ }^{16}$ Onora O'Neill, Constructions of Reason: Explorations of Kant's Practical Philosophy (Cambridge: Cambridge University Press, 1989) ch 6.
} 
autonomy about the character and direction of their own life. ${ }^{17}$ However, a conservative view might also interpret dignity as entailing some constraint, and could foreseeably impose limits on the legitimate sphere of individual choice. ${ }^{18}$

Dignity might also be achieved through recognition, or a relational view of dignity. This sees dignity as expressive, and requires that we act in a way that expresses respect for individuals. ${ }^{19}$ However, receiving this recognition and respect might serve to constrain individual autonomy. ${ }^{20}$ Rosen, for example, sees dignity as being about respect, though not necessarily limited to respect. ${ }^{21}$ For Rosen, this idea is more important for those with power, in relation to how they treat those without power: ${ }^{22}$ if those with power treat those without power without respect, this might come to infringe human dignity. This, then, puts a duty on others to uphold individual dignity, but does not translate into particular rights to dignity. ${ }^{23}$ In a similar but more expansive vein, Clapham sees dignity as having two elements: first, respect for individual humanity;

\footnotetext{
${ }^{17}$ Denise Réaume, 'Dignity, Choice and Circumstances' in Christopher McCrudden (ed), Understanding
} Human Dignity, vol 192 (Proceedings of the British Academy, Oxford: Oxford University Press, 2013) 539.

${ }^{18}$ Roger Brownsword, 'Human Dignity from a Legal Perspective' in Marcus Düwell and others (eds), The Cambridge Handbook of Human Dignity: Interdisciplinary Perspectives (Cambridge: Cambridge University Press, 2014) 1.

${ }^{19}$ Christopher McCrudden, 'In Pursuit of Human Dignity: An Introduction to Current Debates' in Christopher McCrudden (ed), Understanding Human Dignity, vol 192 (Proceedings of the British Academy, Oxford: Oxford University Press, 2013) 41.

20 ibid 40.

${ }^{21}$ Rosen (n 9) 117-18.

22 ibid 75.

${ }^{23}$ McCrudden (n 19) 41. 
and, second, the creation or protection of conditions for individual self-fulfilment, ${ }^{24}$ including taking part in the social life of society, and achieving a decent standard of living. ${ }^{25}$

In broad terms, then, dignity may be conceived of as individual autonomy (in the vein of Kant); and/or as social-respect, with both subjective and materialistic aspects, and based on moral personality (following Rawls). ${ }^{26}$ The view of dignity as social-respect is popular in equality law scholarship: Hepple sees dignity as the need to treat everyone with respect due to their common humanity. ${ }^{27}$ For Dworkin, this recognises the inherent value of human beings, and derives from the assumption of a natural right to equality of concern and respect, ${ }^{28}$ which we possess due to our status as human beings. ${ }^{29}$ Given dignity is inherent in all human beings, then, Fredman argues that it is a more attractive foundation for equality law than other bases, such as rationality, which might operate to exclude individuals from the scope of legal provisions. ${ }^{30}$ 'Dignity' also puts some limits on the leveling down of equality law, and entails some minimum provision to secure individual needs. ${ }^{31}$ It is therefore a more inclusive and substantive basis for equality law than other justifications.

\footnotetext{
24 This could also be expressed as 'autonomy' or 'self-realisation': Andrew Clapham, Human Rights in the Private Sphere (Oxford Monographs in International Law, Oxford: Clarendon Press, 1993) 148. 
There is a tension between a view of dignity as autonomy and a view of dignity as social-respect: in contrast to the autonomy view, which focuses on an individual's own person or humanity, the recognition approach focuses on the community's collective conscience, and sees consent or choice as essentially irrelevant. ${ }^{32}$ That said, there is also potential overlap between the two conceptions: societal respect may be expressed by allowing individual scope for autonomy and choice, within the bounds of social acceptability and securing others' dignity. ${ }^{33}$ Consent and choice, though, must be meaningful: formal procedures for obtaining consent 'may reveal only spurious consent', ${ }^{34}$ so we must ensure both consent and dissent are possible. ${ }^{35}$ Thus, for Rosen, we may secure dignity as both individual freedom and social recognition by limiting individual autonomy to reflect 'true' consent. In the context of human rights law, Clapham sees dignity as potentially involving (at least) four overlapping aspects: (1) prohibiting inhuman treatment, humiliation, or degradation; (2) assuring the possibility for individual choice and the conditions for self-fulfilment, autonomy, or selfrealisation; (3) protecting group identity and culture; and (4) creating the necessary conditions for each individual to have their essential needs satisfied. ${ }^{36}$

While different conceptions of dignity may potentially be reconciled, an emphasis or preference for one view or the other may have serious consequences in

\footnotetext{
${ }^{32}$ Brownsword (n 18) 12.

${ }^{33}$ Onora O’Neill, 'Between Consenting Adults' (1985) 14 Philosophy \& Public Affairs 252, 253.

${ }^{34}$ O’Neill (n 16) 107.

${ }^{35}$ Rosen (n 9) 110.

${ }^{36}$ Andrew Clapham, Human Rights Obligations of Non-State Actors (The Collected Courses of the Academy of European Law v. 15/1, Oxford: Oxford University Press, 2006) 545-46.
} 
practice, particularly in cases where dignity is denied. ${ }^{37}$ If dignity is an inherent aspect of being human, then we would retain our dignity even if it were denied. ${ }^{38}$ Denial, then, would be preventing us from exercising our dignity, ${ }^{39}$ including by treating us in a way in which we do not want to be treated. ${ }^{40}$ Conversely, to uphold dignity, we may need to act in a way that expresses respect for others, and acknowledges that others are entitled to be treated with respect. ${ }^{41}$ Given the individually contingent nature of 'respect', it is unsurprising that what counts as humiliating, degrading or disrespectful varies according to the situation and individuals involved. ${ }^{42}$ It then becomes difficult to draw the boundaries regarding what is 'dignified'. As O'Connell has argued: 'What one person regards as an intolerable assault on human dignity, another may see as incidental, as a part of everyday life. What one person may see as a racist denial of dignity, another may see as legitimate affirmative action.' ${ }^{43}$

Going a step further, if dignity is inviolable and universal, then competing dignity claims will not be able to be balanced. ${ }^{44}$ Dignity may therefore be too absolute to act as a foundation for equality law, as (on an individual autonomy, absolutist view) it denies any ability to balance conflicts with other values or objectives. ${ }^{45}$ Thus, Hepple

\footnotetext{
${ }^{37}$ Rosen (n 9) 101.

38 ibid.

39 ibid.

40 ibid 127.

41 ibid.

42 ibid.

${ }^{43}$ Rory O’Connell, 'The Role of Dignity in Equality Law: Lessons from Canada and South Africa' (2008) 6 Int J Constitutional Law 267, 279.

${ }^{44}$ Rosen (n 9) 107-08.

${ }^{45}$ Fredman (n 1) 24-25; Hepple (n 27) 21.
} 
argues that we should instead look to proportionality as a basis for equality law, ${ }^{46}$ as it facilitates and, indeed, demands this balancing exercise.

On the other hand, if dignity claims can be balanced, then 'dignity' cannot be the source of inviolable rights. ${ }^{47}$ In equality law scholarship, Fredman therefore maintains that dignity should be seen as one aspect of a substantive conception of equality law, to secure a recognition aspect of equality and avoid stereotyping, humiliation and stigma on the basis of protected characteristics. ${ }^{48}$ Using dignity as just one aspect of substantive equality helps to address any inherent weaknesses in the concept. Vickers similarly argues for a model of equality that emphasises the link between equality and individual dignity and identity, and which focuses on self-respect and self-worth. ${ }^{49}$ While this model is better than a focus on formal equality, it still raises significant tensions between the alleged universality of dignity, and the accommodation of individual difference. ${ }^{50}$ That said, it does flag the possibility of balancing competing demands to dignity, via a view of dignity as social-respect.

The implications of dignity for human rights and equal treatment are therefore caught in an ambivalence regarding what dignity actually entails. There is competing support for both the liberal, individualised view of dignity, and for the more social, community oriented view of dignity. ${ }^{51}$ These differing views of dignity are evident in

\footnotetext{
${ }^{46}$ Hepple (n 27) 22.

${ }^{47}$ Rosen (n 9) 109-10.

${ }^{48}$ Fredman (n 1) 25.

49 Vickers (n 31) 148-49.

50 ibid 150.

${ }^{51}$ McCrudden (n 19) 48.
} 
law and legal decision-making, ${ }^{52}$ particularly in relation to medicine, ${ }^{53}$ health care ${ }^{54}$ and the right to die. ${ }^{55}$ Similarly, the notion of 'dignity' in equality law is beset by definitional issues, and is open to multiple, potentially conflicting interpretations ${ }^{56}$ For Smith, 'dignity' is even more imprecise than the idea of 'equality': ${ }^{57}$ while reference to dignity might be helpful to explain and justify a commitment to equality, it does not help to explain what is actually required by the term. 'Dignity' therefore lacks a sufficient theoretical basis to act as the foundation for equality law in the UK. ${ }^{58}$

Dignity, then, is perhaps best conceived of as an institutional notion, which confers on judges (and other decision-makers) discretion to make moral judgments. ${ }^{59}$ Minimal articulation and consensus regarding what is meant by 'dignity' opens the way to judicial and academic manipulation of the term, and for cloaked and unarticulated value judgments to be incorporated into judicial decision-making. ${ }^{60}$ This is consistent with the Canadian experience, where O'Connell has found that 'the concept of dignity

\footnotetext{
52 ibid.

${ }^{53}$ Jeff Malpas and Norelle Lickiss, Perspectives on Human Dignity: A Conversation (Dordrecht:
} Springer, 2007).

${ }^{54}$ Lennart Nordenfelt, 'The Concept of Dignity' in Lennart Nordenfelt (ed), Dignity in Care for Older People (Wiley-Blackwell, 2009).

${ }^{55}$ Scott Cutler Shershow, Deconstructing Dignity: A Critique of the Right-to-Die Debate (Chicago: University of Chicago Press, 2013).

${ }^{56}$ Fredman (n 1) 23; Vickers (n 31) 150.

${ }^{57}$ Nicholas Smith, ‘A Critique of Recent Approaches to Discrimination Law' [2007] N Z L Rev 499.

${ }^{58}$ Vickers (n 31) 151.

${ }^{59}$ McCrudden (n 19) 13.

${ }^{60} \mathrm{O}$ 'Connell (n 43) 280. In the constitutional and human rights context, see similarly Conor O'Mahony, 'There is No Such Thing as a Right to Dignity' (2012) 10 International Journal of Constitutional Law 551. 
[in case law] is sufficiently broad so as to allow judges to invoke unarticulated norms to decide difficult issues. This may reinforce stereotypes and prejudices rather than combat them.' 61

To overcome the criticism that 'dignity' is an inherently subjective and indeterminate idea, it is necessary for decision-makers to explicitly adopt and justify a clear conception or view of what dignity entails. ${ }^{62}$ Thus, O'Connell argues that Canadian judges should publicly declare and clarify the normative basis for legal decisions relying on the concept of dignity, and invite public and academic scrutiny of the notion. ${ }^{63}$ A similar critique may be applied to UK equality law: while dignity is frequently employed by judges to justify and ground their decision-making, there is limited scrutiny and articulation of what 'dignity' actually means in this context. This, then, is explored in the next section.

\section{DIGNITY AND RETIREMENT AGES}

Recognising the potential importance of 'dignity' as a concept in equality law, it is telling to scrutinise how the term is being deployed and relied on in EU and UK decisions in relation to retirement ages. As a relatively recent and controversial protected characteristic, decisions on age force courts to grapple with complex and untested notions of equality, pushing the normative development of the law. Thus, if 'dignity' provides a cloak to allow judges to make difficult normative judgements, the

\footnotetext{
${ }^{61}$ O’Connell (n 43) 284.

${ }^{62}$ Tarunabh Khaitan, 'Dignity as an Expressive Norm: Neither Vacuous Nor a Panacea' (2012) 32 Oxford J Legal Studies 1, 14.

${ }^{63}$ O’Connell (n 43) 285.
} 
law relating to retirement ages is a telling area in which to interrogate the use of 'dignity' and its role in decision-making.

\section{A. 'Dignity' in EU Law}

UK law relating to retirement ages is grounded in the EU's Framework Directive $2000 / 78,{ }^{64}$ which regulates age discrimination in employment. While the Framework Directive prohibits direct and indirect age discrimination in employment and occupation (Articles 1, 2), it also provides for a number of specific exceptions to the principle of equal treatment. Most relevantly, Article 6(1) of the Directive stipulates that Member States may provide that differences of treatment do not constitute discrimination if:

within the context of national law, they are objectively and reasonably justified by a legitimate aim, including legitimate employment policy, labour market and vocational training objectives, and if the means of achieving that aim are appropriate and necessary.

The Framework Directive is also made without prejudice to national provisions laying down retirement ages, ${ }^{65}$ though this has not acted to exclude retirement ages from review. The CJEU has held that retirement ages can be legitimate and proportionate in certain cases, so long as they are objectively and reasonably justified

\footnotetext{
${ }^{64}$ Council Directive 2000/78/EC of 27 November 2000 establishing a general framework for equal treatment in employment and occupation [2000] $O J$ L303/16-22.

${ }^{65}$ See Recital 14 in the Preamble to the Framework Directive.
} 
by a legitimate aim and the means of achieving that aim are appropriate and necessary, in accordance with Article 6(1). ${ }^{66}$

In the context of retirement provisions, the CJEU has endorsed a range of legitimate aims. Most relevantly for our purposes, the Court has held that retirement ages are legitimately aimed at avoiding legal disputes with older employees over their ability to perform their duties ${ }^{67}$ or the need to dismiss older employees on performance grounds ${ }^{68}$ particularly in 'situations which are humiliating for elderly workers' ${ }^{69}$ This implicitly assumes that questioning the capacity of an elderly worker is both humiliating and contrary to that individual's dignity. Thus, a retirement age allows individuals to retire with their dignity intact, as a uniform age involves no individual capacity assessments.

Humiliation is an idea closely related to, but potentially distinct from, dignity. For Margalit, treating each human as human involves treating them without humiliation. ${ }^{70}$ Humiliation might therefore be interpreted as a (negative) core of dignity, providing an inverse understanding of how we achieve dignity through

\footnotetext{
${ }^{66}$ See, eg, Case 411/05 Palacios de la Villa v Cortefiel Servicios SA [2007] ECR I-8531, para 73; Case C-388/07 R (Age Concern England) v Secretary of State for Business Enterprise and Regulatory Reform [2009] 3 CMLR 4; Case C-45/09 Rosenbladt v Oellerking Gebäudereinigungsges [2011] 1 CMLR 32; Case C-250/09 Georgievv Tehnicheski universitet-Sofia, filial Plovdiv [2011] 2 CMLR 7; Joined Cases C-159/10 and C-160/10 Fuchs $v$ Land Hessen [2011] 3 CMLR 47.

${ }^{67}$ Fuchs (n 66) paras 47, 50.

${ }^{68}$ Rosenbladt (n 66) para 43.

${ }^{69}$ Case C-141/11 Hörnfeldt v Posten Meddelande AB [2012] EUECJ C-141/11 (5 July 2012) para 34.

${ }^{70}$ Avishai Margalit, 'Human Dignity between Kitsch and Deification' in Christopher Cordner and Raimond Gaita (eds), Philosophy, Ethics and a Common Humanity: Essays in Honour of Raimond Gaita (Milton Park: Routledge, 2011) 118.
} 
reference to what constitutes indignity. ${ }^{71}$ Thus, 'dignity' might be associated in some contexts with freedom from humiliation. ${ }^{72}$ What is 'humiliating' is likely to vary according to the situation and individuals involved. ${ }^{73}$ Thus, like 'dignity', humiliation is a problematic concept if used as the foundation for the development of generalised legal rules. Further, as McCrudden argues, ‘humiliation' provides a limited foundation for human rights, as 'dignity' understood as humiliation is not sufficiently comprehensive to justify all rights. ${ }^{74}$ Thus, humiliation might be seen as a limited aspect or interpretation of 'dignity', associated with expressive or recognition views. ${ }^{75}$

There is minimal development of this legitimate aim in CJEU case law, though it is repeatedly referenced in cases relating to retirement ages. This is not unusual given how CJEU judgments are usually drafted: indeed, it is the role of national courts to scrutinise the relevance and legitimacy of any legitimate aim. That said, CJEU decisions on this point have given very limited guidance to national courts in relation to how this legitimate aim might be developed.

In Fuchs, the retirement age in question was originally based on an irrebuttable presumption that civil servants were unfit to work after age $65,{ }^{76}$ assuming a correlation between age and capacity. However, the German and Land Hessen Governments argued that the legislature now accepted that people could be fit to work beyond the

\footnotetext{
${ }^{71}$ McCrudden (n 19) 41.

${ }^{72}$ Christopher McCrudden, 'Human Dignity and Judicial Interpretation of Human Rights' (2008) 19

European Journal of International Law 655, 685; Clapham (n 36) 545-46.

${ }^{73}$ Rosen (n 9) 127. In relation to human rights, see further Clapham (n 36) 542-43.

${ }^{74}$ McCrudden (n 19) 41.

75 ibid.

${ }^{76}$ Fuchs (n 66) para 40.
} 
age of 65 , and that the justification no longer underpinned the retirement age. The CJEU held that the law could still pursue a legitimate aim, even if the aims underlying the law had changed over time. ${ }^{77}$ While the German government argued that the creation of a favourable age structure among civil servants was the key aim of the retirement age, the provision was also aimed at avoiding disputes relating to employees' ability to perform their duties beyond the age of 65 . The CJEU did not scrutinise this aim in any depth, or seek to distinguish it from other aims underlying the retirement age, merely concluding:

that the aim of establishing an age structure that balances young and older civil servants in order to encourage the recruitment and promotion of young people, to improve personnel management and thereby to prevent possible disputes concerning employees' fitness to work beyond a certain age, while at the same time seeking to provide a high-quality justice service, can constitute a legitimate aim of employment and labour market policy. ${ }^{78}$

It was for the national court to interpret these rules in the factual and legislative context. $^{79}$

In Rosenbladt, ${ }^{80}$ the German government argued that the automatic termination of employment contracts once an employee reached pensionable age had the:

\footnotetext{
77 ibid para $41-42$.

78 ibid para 50 . See also paras 60,75 .

79 ibid para 72.

${ }^{80}$ Rosenbladt (n 66).
} 
advantage of not requiring employers to dismiss employees on the ground that they are no longer capable of working, which may be humiliating for those who have reached an advanced age. ${ }^{81}$

Without subjecting this to any further interrogation, the CJEU held that aims such as those advocated by the German government must, in principle, be capable of justifying retirement ages ${ }^{82}$ though the dignity or humiliation aim was not a direct focus of the case.

In Hörnfeldt, ${ }^{83}$ the Swedish Government argued that the retirement rule aimed to 'avoid termination of employment contracts in situations which are humiliating for workers by reason of their advanced age' ${ }^{84}$ Again, the CJEU held that this must in principle be a legitimate aim for justifying a retirement age. ${ }^{85}$ In considering whether the retirement rule was appropriate for achieving these aims, the Court merely stated that 'it can also be accepted that the $67-$ year rule, by authorising employers to terminate an employment contract when the employee has reached that age, makes it possible to avoid a situation in which employment contracts are terminated in situations which are humiliating for elderly workers. ${ }^{96}$ This merely repeats the Court's earlier assertion, with little evidence to back up the assessment.

\footnotetext{
81 ibid para 43.

82 ibid para 45.

${ }^{83}$ Hörnfeldt (n 69).

84 ibid para 26.

85 ibid para 30.

${ }^{86}$ ibid para 34.
} 
In sum, then, the CJEU has accepted that avoiding 'humiliating' performance assessments might be a legitimate aim, though it is clearly for national courts to scrutinise whether such an aim might be legitimate in the national context. The CJEU has provided limited guidance as to how this legitimate aim might be developed in practice, and has given minimal clarity regarding where this aim might be relevant or legitimate. However, it is worth noting that no CJEU case has yet relied on avoiding performance disputes or humiliating experiences for older workers as a sole or primary legitimate aim to justify a retirement age; rather, 'dignity' based arguments have always been used in conjunction with other legitimate aims. This may further explain why the judgments contain limited exposition of this aim. Further, it may imply that advocates and courts see 'dignity' as a weaker or less convincing legitimate aim for justifying a mandatory retirement age.

\section{B. 'Dignity' in UK Law}

Given most of the scrutiny of legitimate aims is the role of national courts, it is more informative to consider domestic case law on this point. The Framework Directive was implemented in the UK by the Employment Equality (Age) Regulations 2006, SI 2006/1031 (now incorporated into the Equality Act 2010), which created an exception to age equality law for dismissal on the basis of retirement for workers at or over the age of 65, creating a national default retirement age (the DRA) (reg 30). Employers were also able to retain a normal retirement age lower than 65 if it could be objectively justified.

'Dignity' was a driving rationale of the DRA since its creation. In $R$ (on the application of Age UK) v Secretary of State for Business, Innovation \& Skills, ${ }^{87}$ the

\footnotetext{
${ }^{87}$ [2009] EWHC 2336 (Admin), [2010] 1 CMLR 21 (‘Age UK’).
} 
DRA was challenged as being inconsistent with the Framework Directive. The evidence put forward by the UK Government depicted 'dignity' as a benefit of the retirement age, which would contribute to the legitimate aim of workforce planning. In the Government's submissions, a retirement age would protect 'the dignity of workers at the end of their working lives' ${ }^{88}$ This was further described as follows:

The Government took the view that the default retirement age was needed to protect the dignity of workers by avoiding a situation in which employers were obliged to dismiss elderly employees on grounds of declining competence at the end of an otherwise unblemished career. It considered that this would be an undignified end to a valuable working life, which would be painful to both sides and likely to damage industrial relations. ${ }^{89}$

Retirement ages would also promote the participation of older workers in the economy, as employers could engage them without fears of declining capability:

Those employers who would otherwise be concerned about recruiting older workers because of the possible need to deal with their declining competence at a later stage, can recruit such workers in the knowledge that they can retire them without the uncertainty of when and how their working lives will end. ${ }^{90}$

\footnotetext{
88 ibid [72].

${ }^{89}$ ibid [74].

90 ibid [75].
} 
These arguments were accepted by the court in Age UK. ${ }^{91}$ In assessing whether the dignity argument was a legitimate aim, Mr Justice Blake was purely concerned with evaluating the sufficiency of the government's reasons. According to His Honour, this did not require him to "set out the substance of the policy debates and the strength or weakness of the material supporting the relevant arguments ${ }^{\prime 92}$ or, indeed, to scrutinise these weaknesses in detail. ${ }^{93}$ Rather, the Court regarded the CJEU's requirement for 'evidence over generalisations' as merely a way of 'deprecating stereo-typical reasoning', rather than requiring proof of social policy justifications. ${ }^{94}$

Thus, the Court rejected the argument that 'dignity' rationales were based on stereotypical assumptions about competence and ageing, and generalisations about competence rather than evidence:

I do not conclude that the government adopted the idea of a DRA on the basis of any generalised assumption that people over 65 are not reasonably capable of competent performance of their duties, or as a class are more likely to be incompetent then people below that age. A concern of employers, noted in the Warman Report was the difficulty of addressing fading competence grounds generally with dignity, and a reluctance to be required to employ competence testing as a sanction for older workers because of the detrimental effect upon morale, but that was not the government's aim in adopting this provision. In any

\footnotetext{
91 ibid [103].

92 ibid [78].

${ }^{93}$ See ibid [90].

94 ibid [107].
} 
event social perceptions are a factor that the government may take into account in implementing the directive as long as its core principles are not undermined. ${ }^{95}$

This final sentence opens the door to the inclusion of stigma, stereotypes and unfounded assertions in the creation of government policy. It is therefore of serious concern. Indeed, this was acknowledged in the Court's consideration of the proportionality of a DRA of 65 :

even assuming that at some point in later working life questions of dignified exit from employment arise, the literature review ... suggested there was no evidence that was a problem between the ages of 65 and $70 \ldots[\mathrm{I}] \mathrm{t}$ is likely that if employers had adverse perceptions [of older workers] those were precisely the results of stereo-typical thinking. ${ }^{96}$

While the challenge to the DRA failed in Age $U K$, the Employment Equality (Repeal of Retirement Age Provisions) Regulations 2011, SI 2011/1069 have since removed the DRA from UK law. From 1 October 2011, it has no longer been possible to retire an employee using the DRA. Under the new Regulations, employers may still implement an employer-justified retirement age ('EJRA') so long as the requirement can be objectively justified as a proportionate means of achieving a legitimate aim.

In Seldon v Clarkson Wright \& Jakes (A partnership), ${ }^{97}$ the UK Supreme Court considered whether a retirement age of 65 in a law firm partnership deed was justified.

\footnotetext{
95 ibid [108].

96 ibid [118].

${ }^{97}$ Seldon (n 2).
} 
The DRA did not apply to members of a partnership: reg 30, which established the DRA, provided that employees at or over the age of 65 could be dismissed on the basis of retirement. In the Seldon case, the firm's partnership deed applied to partners, not employees. Thus, the retirement age needed to be justified as necessary and proportionate in the interests of the partnership (the same test that now applies to all retirement ages).

At first instance, the Employment Tribunal (ET) in Seldon held that the retirement age was an appropriate means of avoiding the need to confront or expel underperforming partners, contributing to the congenial and supportive culture within the partnership. ${ }^{98}$ This would also prevent the partner from 'suffering the indignity' of ending his partnership on that basis ${ }^{99}$ and of being put through a performance management procedure ${ }^{100}$ after years of loyal service to the firm ${ }^{101}$ and a 'long and distinguished career'. ${ }^{102}$ Performance management was seen as a 'difficult and contentious process' ${ }^{103}$ that would be a 'demeaning affront to the Partner's dignity.' 104 The use of retirement ages allowed other partners to 'avoid facing an under-performing Partner who is nearing retirement' and enabled an under-performing partner to 'coast' towards retirement. ${ }^{105}$ It was 'not unreasonable to assume that some Partners who have

\footnotetext{
${ }^{98}$ Seldon v Clarkson Wright \& Jakes [2007] UKET 1100275/2007 (4 December 2007) [67], [54.5][54.8].

99 ibid [65].

${ }^{100}$ ibid [61.6].

101 ibid [61.7].

102 ibid [59.2].

${ }^{103}$ ibid [61.7]

${ }^{104}$ ibid [60.6]. See also at [59.6].

${ }^{105}$ ibid [59.4]
} 
reached the age of 65 are not able to make as great a contribution as they had done in the past' ${ }^{106}$ supporting the need for an alternative to performance management.

On appeal, the Employment Appeal Tribunal (EAT) rejected this conclusion. ${ }^{107}$ The EAT held that it was a legitimate aim to 'desire to run the operation in a collegiate way and to structure the partnership agreement to achieve that effect', and the ET was entitled to conclude that limited disciplinary procedures for under-performance were directed to achieving that aim. ${ }^{108}$ However, the rule in this case was based on an assumption that performance declined after the age of $65 .{ }^{109}$ No evidence was put forward to support this assumption, and the 'sketchy material' that was produced as evidence suggested that performance did not decline until age $70 .{ }^{110}$ Thus, there was no evidence to support a retirement age of 65 in this case, though evidence could conceivably be produced to justify a retirement age. ${ }^{111}$ According to the EAT:

It would not necessarily be surprising if there were to be general recognition that the contribution made by partners became less significant after a particular age. It may also be that the desire not to subject partners to a performance regime, possibly leading ultimately to expulsion, would justify imposing a

\footnotetext{
${ }^{106}$ ibid [59.8].

${ }^{107}$ Seldon v Clarkson Wright \& Jakes [2008] UKEAT 0063_08_1912, [2009] IRLR 267.

${ }^{108}$ ibid [68]-[69].

109 ibid [70].

110 ibid [70].

111 ibid [71].
} 
general retirement age (which could in an appropriate case conceivably be below 65$).{ }^{112}$

The Court of Appeal also endorsed a 'dignity' aim. Sir Mark Waller said:

It seems to me that an aim intended to produce a happy work place has to be within or consistent with the Government's social policy justification for the regulations. It is not just within partnerships that it may be thought better to have a cut-off age rather than force an assessment of a person's falling off in performance as they get older. ... [M]y experience would tell me that it is a justification for having a cut-off age that people will be allowed to retire with dignity. ${ }^{113}$

In reviewing the validity of this 'dignity' argument, the Supreme Court noted the importance of putting 'stereotypical assumptions out of our minds', including those related to age and capacity: 'These assumptions no longer hold good (if they ever did) in times of increasing longevity'. ${ }^{114}$ Lady Hale described 'dignity' aims as being:

variously put as avoiding the need to dismiss older workers on the grounds of incapacity or underperformance, thus preserving their dignity and avoiding

\footnotetext{
112 ibid [71].

${ }^{113}$ Seldon v Clarkson Wright \& Jakes [2010] EWCA Civ 899, [2011] 1 CMLR 5 [22]-[23].

${ }^{114}$ Seldon (n 2) [15].
} 
humiliation, and as avoiding the need for costly and divisive disputes about capacity or underperformance. ${ }^{115}$

Dignity-based aims were seen to be 'controversial', particularly given 'the assumptions underlying these objectives look suspiciously like stereotyping' as they conflate age with capacity. ${ }^{116}$ Despite recognising the risks of stereotyping, the Supreme Court accepted 'dignity' aims as being one of two classes of legitimate aims (the other being intergenerational fairness). ${ }^{117}$ Rather than question the CJEU's decision that 'the avoidance of unseemly debates about capacity is capable of being a legitimate aim', the Supreme Court appeared reluctantly to endorse dignity as a legitimate aim. ${ }^{118}$

Accepting dignity as a legitimate aim in the UK was a surprising decision by the Supreme Court, particularly in the context of the remainder of Lady Hale's judgment. Lady Hale appeared to endorse Age UK's argument that the underlying idea of anti-discrimination law 'is the dignity of each individual, the right to be treated equally irrespective of either irrational prejudice or stereotypical assumptions which may be true of some but not of others. ${ }^{119}$ It would therefore have been open to the Supreme Court to reject dignity as a legitimate aim for justifying retirement ages in the

\footnotetext{
115 ibid [57].

116 ibid [57].

117 ibid [56]-[57].

118 ibid [58].

119 ibid [57].
} 
$\mathrm{UK},{ }^{120}$ as compulsory retirement undermines the equal treatment of individuals of different ages, and is grounded in stereotypical assumptions regarding age and capacity. However, this was not the course adopted by the Supreme Court.

The Supreme Court referred the issue of proportionately back to the ET. When reconsidered by the ET, the collegiality aim was not raised due to a lack of evidence. ${ }^{121}$ Thus, there was no finding on proportionality in relation to the dignity aim. This, then, flags the difficulty of producing evidence to support the legitimacy of dignity-based arguments, and the importance of the proportionality assessment to any discussion of dignity as a legitimate aim.

Later cases have continued to endorse dignity as a legitimate aim, though - as in Seldon - it appears to be difficult for employers to justify a retirement age on this basis: most employers are unsuccessful at showing that a dignity-based retirement age is proportionate. Dignity-based proportionality arguments are more likely to succeed where performance management is difficult or impossible. In Willey $v$ England and Wales Cricket Board Ltd, ${ }^{122}$ dignity was regarded as a legitimate aim, given the difficulty of assessing umpires' performance, the collaborative approach adopted to the management of umpires, ${ }^{123}$ and the lack of uniform performance assessments. ${ }^{124}$ However, there was no evidence of age-related decline among umpires at the age of 65 ,

\footnotetext{
${ }^{120}$ Indeed, this would be open to the Court regardless: while the Luxembourg court has 'held that the avoidance of unseemly debates about capacity is capable of being a legitimate aim' (emphasis added), it is ultimately up to national courts to determine whether it is legitimate within the meaning of Article 6(1): Age Concern (n 66).

${ }^{121}$ Seldon v Clarkson Wright \& Jakes [2013] UKET 1100275/2007 (14 May 2013) [8], [36].

${ }^{122}$ [2015] UKET 2201406/2014 (10 March 2015) [8.15], [8.16].

${ }^{123}$ ibid [8.15], [8.16].

124 ibid [44].
} 
meaning a higher retirement age could still uphold their dignity. ${ }^{125}$ It was therefore not appropriate or reasonably necessary to adopt a retirement age of 65. In Lindsay v Department for Employment and Learning, ${ }^{126}$ capability assessments for older panel members of the Northern Ireland Industrial Tribunals were not seen as a viable alternative to a retirement age: according to the ET, 'there is no proportionate and suitable means of assessing, on a regular basis, the continuing fitness of panel members' given the time and cost of capability processes, the possibility of litigation, the impact on panel members' dignity, and risks to panel members' independence. ${ }^{127}$ Similarly, in White $v$ Ministry of Justice, ${ }^{128}$ performance management for judges was seen as 'not only distasteful and undignified but potentially damaging to the rule of law' ${ }^{129}$

As these cases illustrate, to support a retirement age, the dignity aim must not only be legitimate: it must also be legitimate in the particular employment context. So, as noted by Lady Hale in Seldon,

Avoiding the need for performance management may be a legitimate aim, but if in fact the business already has sophisticated performance management measures in place, it may not be legitimate to avoid them for only one section of the workforce. ${ }^{130}$

\footnotetext{
125 ibid [45]-[48].

${ }^{126}$ [2013] NIET 356/12 (19 December 2013), [2014] EqLR 180.

127 ibid p 16.

128 [2014] UKET 2201298/2013 (25 November 2014).

${ }^{129}$ ibid [45].

${ }^{130}$ Seldon (n 2) [61].
} 
This likely means that only a limited sub-set of employers can rely on dignity-based arguments to support a mandatory retirement age, as in professions with limited scope to implement performance management, or where performance systems are underdeveloped. Limiting the legitimate aim in this way may reflect an awareness among the judiciary of the risks of a dignity-based approach to justifying mandatory retirement ages. However, endorsing the use of dignity arguments in this context may actually deter employers from developing performance processes for their workforce. Thus, it may stultify the development of good workplace practices, and is contrary to the government's policy agenda. ${ }^{131}$

\section{Assumptions Underlying the 'Dignity' Argument}

Overall, then, CJEU and UK cases show a growing reliance on other legitimate aims, particularly those grounded in intergenerational fairness, to justify retirement ages. This may reflect a move away from dignity-based legitimate aims, and may mean that dignity-based arguments are only one factor considered in determining whether retirement ages are objectively justified, which is not given substantial weight by the court in the ultimate proportionality assessment. Indeed, it appears difficult for employers to rely on dignity-based arguments in practice.

That said, at a symbolic level, courts recognising dignity-based aims may still be problematic, even if this is not determinative of most court decisions. The 'dignity' argument only holds if we accept a number of intertwined propositions. At a basic level, the argument assumes that older workers have inherent dignity, which will be taken away if subjected to performance management. This may be broken down further into

\footnotetext{
${ }^{131}$ Michael Connolly, 'The Coalition Government and Age Discrimination' [2012] Journal of Business Law 144, 149-50.
} 
six key propositions: first, that individuals have inherent dignity; second, that individual capacity may decline with age; third, that declining capacity with age is stigmatic, and that it is humiliating to be associated with declining capacity; fourth, that any questioning of age-based decline will therefore be humiliating; fifth, that individual performance appraisals and capability processes are therefore innately humiliating for older workers, and that processes cannot manage or minimise this impact; and, sixth, that individual dignity is upheld by not being exposed to humiliating experiences, and that dignity is therefore upheld by removing individuals from employment at a fixed age. These propositions are seriously questionable, and may be critiqued on theoretical and empirical grounds.

First, the whole premise of dignity in the case law is dependent on a Kantian notion of dignity as worth, which sees every individual (including older workers) as deserving to be treated in a manner consistent with the high worth of the human species. ${ }^{132}$ This is only one view of the basis for dignity, and is itself grounded in assumptions about the nature of dignity and the human species. ${ }^{133}$

Second, there is no evidence that age uniformly affects capacity, such that individual capacity declines with age: indeed, chronological age is a bad predictor of capability, as people age at different rates and in different ways. Older workers therefore form a more heterogeneous group than their younger counterparts, ${ }^{134}$ and any assumed link between age and capacity is more likely a case of age-based stereotyping. Indeed, some skills improve with age, meaning a blanket assumption of (in)capacity is

\footnotetext{
${ }^{132}$ Kateb (n 10) 3-4.

133 ibid 5.

${ }^{134}$ Brenda Barrett and Malcolm Sargeant, 'Working in the UK without a Default Retirement Age: Health, Safety, and the Oldest Workers' (2015) 44 Ind Law J 75, 99.
} 
inappropriate and unhelpful. Age has limited impact on cognitive work performance in particular, as the 'interplay between several diminishing [and] increasing mental subcapacities' leaves capacity as a whole unaffected, and work experience compensates for any diminishing capacity. ${ }^{135}$ For white collar or professional roles in particular, then, age and capacity are not uniformly linked; even for manual work, though, ageing will affect individuals differently and at different rates. Thus, uniform rules are unlikely to accommodate the heterogeneity of older workers.

Third, while declining capacity with age might be stigmatic, this is not a good basis for legal decision-making, and serves to embed age stereotypes in equality law. It is clear that ageing is seen as stigmatic in many Western societies, ${ }^{136}$ including by younger people, employers and the elderly themselves. ${ }^{137}$ Drawing on a meta-study of the age stereotypes literature, Posthuma and Campion found stereotypes that 'older workers have lower ability, are less motivated, and are less productive than younger employees.' ${ }^{138}$ In focus groups with Scottish employers, Loretto and White found that the majority thought that performance decreased from age 50, particularly in manual

\footnotetext{
${ }^{135}$ René Schalk and others, 'Moving European Research on Work and Ageing Forward: Overview and Agenda' (2010) 19 European Journal of Work and Organizational Psychology 76, 87.

${ }^{136}$ Sonia K Kang and Alison L Chasteen, 'The Development and Validation of the Age-Based Rejection Sensitivity Questionnaire' (2009) 49 The Gerontologist 303.

${ }^{137}$ Elaine Dewhurst, 'Are Older Workers Past Their Sell-by-Date? A View from UK Age Discrimination Law' (2015) 78 Modern Law Review 189, 190-97.

${ }^{138}$ Richard A Posthuma and Michael A Campion, 'Age Stereotypes in the Workplace: Common Stereotypes, Moderators, and Future Research Directions' (2009) 35 Journal of Management 158, 166. See also Wendy Loretto, 'Work and Retirement in an Ageing World: The Case of Older Workers in the UK' (2010) 5 Twenty-First Century Society 279, 286.
} 
roles. ${ }^{139}$ These stereotypes are inconsistent with empirical evidence on the impact of ageing: performance often improves with age, and any decline is generally small; ${ }^{140}$ individual skill and health are far more important predictors of capability. ${ }^{141}$

While age stereotypes are generally unfounded, they still have a significant practical impact. Older people often internalise age stereotypes, which can lead to concerns about fulfilling a stereotype, which then leads to declining performance - a phenomenon known in the psychology literature as 'stereotype threat'. ${ }^{142}$ Older people do experience disadvantages when they are seen as 'old' ${ }^{143}$ Thus, being associated with the process of ageing might be stigmatic, and may lead to declining performance by older workers, even where their physical capacity is not affected by ageing. Though there is some truth to the idea that declining capacity with age is stigmatic, it would be more effective to seek to address age stereotypes and discrimination against older workers, rather than to embed and reinforce these arguments within equality law. ${ }^{144}$ According to Ballenger, the best way to address age stigma - which is derived from

\footnotetext{
${ }^{139}$ Wendy Loretto and Phil White, 'Employers' Attitudes, Practices and Policies towards Older Workers' (2006) 16 Human Resource Management Journal 313, 320-21.

${ }^{140}$ Posthuma and Campion (n 138) 166.

${ }^{141}$ ibid.

${ }^{142}$ Kang and Chasteen (n 136); Ruth A Lamont and others, 'A Review and Meta-Analysis of Age-Based Stereotype Threat: Negative Stereotypes, Not Facts, Do the Damage' (2015) 30 Psychology and Aging 180.

${ }^{143}$ Kang and Chasteen (n 136).

${ }^{144}$ Therese MacDermott, 'Older Workers and Extended Workforce Participation: Moving beyond the “Barriers to Work" Approach' (2014) 14 International Journal of Discrimination and the Law 83, 89. Though there is no doubt that stereotypes are embedded in equality law: see the discussion of compensation in Dewhurst (n 137).
} 
ignorance and mystification - is through science and education. ${ }^{145}$ Thus, educating both workers and employers about the potential impact (if any) of age on capacity, and how it could be addressed, would be a more effective route to progress than the forced removal of workers at a particular age. Allowing stigma to dictate law runs directly counter to the objectives of equality law. Retirement ages may reinforce age-based assumptions and the stigma of ageing, as they symbolically support the idea that agerelated decline necessitates older workers' removal from the workforce.

Similarly, and fourth, the questioning of age-based decline (such as through performance processes) might be humiliating where ageing is seen as stigmatic. ${ }^{146}$ However, performance processes might also provide an opportunity for evidence-based education of employers and employees, particularly where a worker retains their full capacity to work. Thus, the questioning of individual capacity may allow workers to demonstrate their ongoing capability, thereby addressing and dispelling age-related stigma and stereotypes.

However, if older workers are inherently or particularly vulnerable, then performance processes might put them at a distinct disadvantage. If this is the case, older workers may be unable to actively participate in any questioning of age-based decline, meaning performance management becomes inherently problematic for older workers. These concerns undersell significantly older workers' skills and capabilities, and ignore the diversity of the older working population. These arguments are more likely to reflect age stereotypes about declining capacity than any actual vulnerability

\footnotetext{
${ }^{145}$ Jesse F Ballenger, 'The Biomedical Deconstruction of Senility and the Persistent Stigmatization of Old Age in the United States' in Annette Leibing and Lawrence Cohen (eds), Thinking About Dementia: Culture, Loss, and the Anthropology of Senility (Rutgers University Press, 2006).

${ }^{146}$ Fredman (n 7) 45.
} 
on the part of older workers. To the extent older workers are disadvantaged in contemporary social conditions, this is largely driven by ageist behaviour and discrimination, which equality law should try to eliminate, rather than embody and endorse.

Following from this, there is no evidence that individual performance appraisals are innately or intrinsically humiliating: when managed well, there is no reason why individual capacity and performance assessments need to be humiliating for any worker, regardless of age. Ongoing developmental performance assessments are a prominent feature of many workplaces. Assessments provide a structured way for employers and employees to review progress, set goals for future development and consider career progression. Thus, they are an instrumental component of many human resource strategies. Where implemented sympathetically, and with a view to individual development, performance appraisals can be rewarding and informative for both employers and employees. Indeed, the UK government's view is that 'dignity is preserved by performance management. ${ }^{147}$

There is therefore no evidence that such processes are inherently humiliating; though, like any process, some employers could use them in a negative way. Implementing effective and sympathetic performance management at the organisational level is a challenging process in practice: thus, it is essential not to adopt an overly optimistic view of the potential of performance management. Performance processes are more likely to be humiliating, however, where they import stereotypes about older workers' capability. Individual assessment is never entirely objective, and will generally be based on norms developed by dominant groups, which indirectly

${ }^{147}$ Connolly (n 131) 149-50 (emphasis in original). 
disadvantage other workers. ${ }^{148}$ Supervisors often have status-based and positional power in an organisation, ${ }^{149}$ and have discretion in how they ignore or invoke performance policies, even in a formalised environment. Thus, we need to be attuned to 'procedures and rules that are arguably neutral but that can, in fact, be discriminatorily applied or used in targeted, detrimental ways toward a particular group'. ${ }^{150}$ Age stereotypes are pervasive in the workplace,,${ }^{151}$ and are often directed towards individual competencies ${ }^{152}$ and subjective assumptions about individual competence. ${ }^{153}$ These stereotypes might lead managers to deploy performance processes in discriminatory ways, to the detriment of older workers. Indeed, age stereotypes have been shown to influence the outcomes of employment-related decisions in a variety of settings, including lower ratings in performance appraisals. ${ }^{154}$ Stereotypes may also prevent employers from considering and offering developmental training, workplace learning and support for older workers. ${ }^{155}$ Unequal access to

\footnotetext{
${ }^{148}$ Fredman (n 7) 39-41.

${ }^{149}$ Vincent J Roscigno and others, 'Age Discrimination, Social Closure and Employment' (2007) 86
} Social Forces 313, 316.

150 ibid 317.

151 ibid 330.

152 ibid 317, 323. See also Philip Taylor and Alan Walker, 'Employers and Older Workers: Attitudes and Employment Practices' (1998) 18 Ageing \& Society 641, 650.

${ }^{153}$ Roscigno and others (n 149) 318. See Vanesa Fuertes and others, 'Extending Working Lives: Age Management in SMEs' (2013) 35 Employee Relations 272, 284-85.

${ }^{154}$ Posthuma and Campion (n 138) 163, 171.

${ }^{155}$ Loretto (n 138) 285-86. See also Schalk and others (n 135) 88; Hendrik P Van Dalen and others, 'Dealing with Older Workers in Europe: A Comparative Survey of Employers' Attitudes and Actions' (2009) 19 Journal of European Social Policy 47, 53; Loretto and White (n 139) 321; Ken Mayhew and others, 'Upskilling Older Workers' [2008] Ageing Horizons 13, 19; Marjorie Armstrong-Stassen and 
training may then lead to declining productivity. ${ }^{156}$ Even when not importing age stereotypes, performance management processes may disadvantage older workers by requiring 'synchronous equality based on continual comparison with younger employees', ${ }^{157}$ ignoring differences in individual age and capacity, and unwittingly forcing older workers out of employment at an earlier age. ${ }^{158}$ Thus, ensuring that performance management does not infringe individual dignity requires broader reforms to address age stereotypes and managerial biases against older workers, and a more nuanced managerial understanding of older workers' particular needs in conducting development reviews. Achieving this end should be an objective of age equality law.

Of course, even if performance management is positive for an individual older worker and helps to protect their autonomy, if it is contrary to the community's collective conscience it might still be avoided for the good of others. As well as protecting other older workers (who might not benefit from performance management), individual managers may wish to avoid management processes for their older staff, on

Seung Hwan (Mark) Lee, 'The Effect of Relational Age on Older Canadian Employees' Perceptions of Human Resource Practices and Sense of Worth to Their Organization' (2009) 20 The International Journal of Human Resource Management 1753, 1755.

${ }^{156}$ See Teh Eng Choo, 'The Aging Workforce: Some Implications, Strategies and Policy Considerations for Human Resource Managers' (1999) 37 Asia Pacific Journal of Human Resources 60; Pnina AlonShenker, 'The Unequal Right to Age Equality: Towards a Dignified Lives Approach to Age Discrimination' (2012) 25 Can J L \& Jurisprudence 243.

${ }^{157}$ Vanessa Beck and Glynne Williams, 'The (Performance) Management of Retirement and the Limits of Individual Choice' (2015) 29 Work Employment Society 267, 271. See also Michael White, 'Older Employees under Pressure? Theorizing Reasons for Declining Commitment' (2012) 26 Work Employment Society 447, 450-51.

${ }^{158}$ Beck and Williams (n 157) 272-73. 
the basis that it infringes their view of social dignity for their staff. This is consistent with the results of organisational case studies of English firms conducted by McNair and others: while employers often cited the 'dignity' argument in their justification for adopting a retirement age and refusing requests to stay beyond retirement age, the authors felt 'in some cases [the dignity argument] looked more like an evasion of managerial responsibility' and a way to avoid discussions of support or training for older workers. ${ }^{159}$ Thus, 'dignity' can be used to reinforce traditional regimes, ${ }^{160}$ and embed stereotypes and norms. Retirement ages, as upheld by the dignity argument, could therefore be seen as a means of social closure, which serves to exclude the elderly from employment. Again, we need to question whether equality law should be playing this role.

Finally, we must consider whether dignity is best upheld through avoiding humiliating experiences for older workers by removing individuals from employment at a fixed age. As detailed in Part 1, there is no consensus as to the core requirements for 'dignity', and how this might play out in an employment context. If we view dignity as individual autonomy (in the vein of Kant), then dignity would be best upheld by giving older workers the choice as to whether to be involved in a capacity or performance assessment. Some would certainly prefer to avoid this process; others would relish the opportunity to prove their worth. Fixed retirement ages deny individuals the opportunity to exercise their autonomy, undermine individual choice

\footnotetext{
${ }^{159}$ Stephen McNair and others, 'Employer Responses to an Ageing Workforce: A Qualitative Study' (Research Report, London, 2007) 8.

${ }^{160}$ In relation to gender, see Annika Thiem, 'Human Dignity and Gender Inequalities' in Marcus Düwell and others (eds), The Cambridge Handbook of Human Dignity: Interdisciplinary Perspectives (Cambridge: Cambridge University Press, 2014) 502.
} 
and diversity, and are therefore inconsistent with an autonomy-based conception of dignity. ${ }^{161}$ Indeed, retirement ages may do harm to the honouring of individual capacity for choice. ${ }^{162}$

However, if we view dignity as consisting of social-respect, following Rawls, then there is far more scope to debate which path offers greater dignity. Some would view social-respect as being derived from having a voice in proceedings, and being able to respond to any questions of capacity. Others would view social-respect as retiring on an adequate pension, with no question of capacity being raised and no interrogation of older workers' performance or qualifications. This latter perspective is the dominant view in the existing case law. Indeed, a key factor in the proportionality test applied by courts is whether workers are entitled to a 'not unreasonable' pension following retirement: ${ }^{163}$ if so, retirement rules will not 'unduly prejudic[e] the legitimate claims of workers'. ${ }^{164}$

If an adequate pension is not on offer, social-respect might require that individuals be allowed to remain in employment, so as to secure a decent standard of living. ${ }^{165}$ That said, even in cases with an inadequate retirement income, the CJEU has held that retirement rules are likely to be proportionate if an employee is able to continue working after being retired, either with their current employer or with a

\footnotetext{
${ }^{161}$ Fredman (n 7) 45.

${ }^{162}$ Réaume (n 17) 540.

${ }^{163}$ Palacios (n 66) para 73; Georgiev (n 66) para 54; Rosenbladt (n 66) paras 43, 48; Fuchs (n 66) paras 66-67; Hörnfeldt (n 69) para 42.

${ }^{164}$ Palacios (n 66) para 73; Georgiev (n 66) para 54; Fuchs (n 66) para 66.

165 cf Khaitan (n 62) 8, who expressly distinguishes dignity from the consequent harms of actions.
} 
different company ${ }^{166}$ or under a different type of employment arrangement, such as a fixed-term contract. ${ }^{167}$ The risk in these situations, of course, is that older workers may be unable to return to the labour market once they have lost their job, ${ }^{168}$ particularly given the prevalence of age discrimination in recruitment. Thus, expecting older workers to apply for a new job may actually undermine social-respect.

Thus, there are contrasting and conflicting approaches to how we uphold dignity, depending on how we define and interpret 'dignity' as a concept, the way we normatively see that interpretation as being best achieved, and the particular factual circumstances to which that interpretation is being applied. This differs according to whether we adopt an autonomy or social-respect approach to dignity, but also within those conceptions. A multi-factor approach to dignity (like that put forward by Clapham) does not help to conclusively resolve these tensions in practice. This, then, further illustrates the complexity and potential indeterminacy of dignity-based arguments.

\section{RECONCEIVING THE 'DIGNITY' ARGUMENT}

If we reject the existing dignity argument as being based on flawed assumptions and stereotypes, it is important to consider what we might instead mean by 'dignity' in this context, and whether mandatory retirement or some other process might best achieve it. If dignity is to be retained as a justification of age equality law, I argue for a view of dignity that accommodates arguments grounded in individual autonomy, while still

\footnotetext{
${ }^{166}$ Rosenbladt (n 66) paras 73-76; Fuchs (n 66) para 66.

${ }^{167}$ Hörnfeldt (n 69) para 40-41.

168 See, eg, Malcolm Sargeant, 'United Kingdom' in Malcolm Sargeant (ed), The Law on Age Discrimination in the EU (Alphen aan den Rijn: Kluwer Law International, 2008) 224.
} 
accommodating social-respect. Key to this will be preventing the use of stereotypical assumptions in organisational decision-making, including in relation to retirement. This is consistent with broader scholarship on age discrimination law: Dewhurst sees its 'central aim' as 'protect[ing] the dignity of the worker from stereotypical assumptions relating to their age.' ${ }^{169}$ Similarly, MacDermott has argued that any approach based on dignity 'should be premised on individual assessment and on equal concern and respect for the individual.' ${ }^{170}$ Thus, a more nuanced view of dignity does not require the exclusion of older workers from employment at a particular age: rather, it might prohibit their exclusion from the workplace on the basis of stereotypical assumptions. In this view, dignity does not self-evidently support mandatory retirement ages; rather, it would question their retention in the majority of circumstances. Any (re)consideration of retirement ages will involve a complex balancing exercise between the interests of employers and employees; there is no ideal solution for how best to achieve dignity in this context. However, three ideas might help to further develop the notion of 'dignity' adopted in age equality law: Alon-Shenker's 'dignified lives' approach to age discrimination; individual consent; and general theory on dignity at work, including humanistic human resource management.

\section{A. A 'Dignified Lives' Approach}

Alon-Shenker's dignified lives approach to age discrimination, developed in the Canadian context, provides one means of reinterpreting dignity in the UK. Drawing on Kantian ideas, Alon-Shenker sees all individuals as being of equal moral worth, and argues that each person should be treated with equal concern and respect at any given

\footnotetext{
${ }^{169}$ Dewhurst (n 137) 194.

${ }^{170}$ MacDermott (n 144) 89.
} 
time. ${ }^{171}$ To achieve this in practice, the theory proposes five substantive principles of equality: individual assessment, equal influence, sufficiency, social inclusion and autonomy. Where age distinctions mean these principles are infringed - such as where unequal treatment is grounded in stereotypes, excludes older workers from participation in social life, or reduces autonomy - then Alon-Shenker argues that the discrimination should be unlawful. While Alon-Shenker's ideas reflect a multi-dimensional approach to age equality, ${ }^{172}$ they are grounded in a highly individualised notion of age equality, which ignores any collective or solidarity dimension of equality law. This, then, appears to prefer an autonomy-based notion of dignity over the more collective orientation of social-respect. While Alon-Shenker's ideas offer one path to re-orient our view of dignity towards autonomy, it is necessary to also accommodate social-respect in any recasting of the notion of dignity.

Mandatory retirement ages would be seen as highly problematic for a dignified lives approach to age discrimination. Retirement ages are largely grounded in stereotypes or prejudice regarding the capacity of older workers, and prevent assessment on individual merits; ${ }^{173}$ might deny older workers access to a minimum level of income, even where pensions are inadequate; ${ }^{174}$ exclude older workers from full and meaningful participation in work; and reduce individual autonomy, choice and free will by eliminating voluntary decision-making regarding when to retire. ${ }^{175}$ Treating people as part of a group by imposing uniform retirement ages can impinge

\footnotetext{
${ }^{171}$ Alon-Shenker (n 156) 252.

${ }^{172}$ See similarly Fredman (n 1) 25-33.

${ }^{173}$ Alon-Shenker (n 156) 262.

174 ibid 271-73. See the discussion of pensions in CJEU proportionality assessments in Part 3(c) above.

175 ibid 278.
} 
upon individual autonomy, ${ }^{176}$ which is a wrong against the individual. ${ }^{177}$ That said, Alon-Shenker does not uniformly condemn mandatory retirement: rather, the theory 'may allow a contractual agreement based on a deferred compensation model requiring employees to retire at the age of $65 \ldots$ if the agreement is drafted in line with the five substantive principles of equality.' 178 This, then, requires a focus on individual consent to retirement ages, which was a key issue in Seldon and highly relevant to the proportionality assessment in UK cases on retirement ages.

\section{B. Individual Consent}

Alon-Shenker's focus on individual consent is consistent with the case law of both the CJEU and UK courts: a retirement rule has been held to be more likely to satisfy the proportionality assessment if it has been collectively bargained or tailored to the circumstances of the case, ${ }^{179}$ thereby embodying a degree of individual consent. This reflects the argument that retirement ages:

should not be regarded as blanket age discrimination, but rather as part of a mutually agreed company personnel policy, or collective agreement, generally negotiated by individuals with reasonable bargaining power. [They] should only

\footnotetext{
${ }^{176}$ Gazi Islam, 'Recognizing Employees: Reification, Dignity and Promoting Care in Management' (2013) 20 Cross Cultural Management: An International Journal 235, 240.

177 Alon-Shenker (n 156) 255.

178 ibid 281.

${ }^{179}$ Palacios (n 66) para 74; Rosenbladt (n 66) paras 49-50, 67-69; Hörnfeldt (n 69) para 32.
} 
be banned if there are explicit reasons for governments to override such private contractual arrangements. ${ }^{180}$

A focus on individual consent in the proportionality assessment reflects a focus on individual autonomy, and could be seen as counter-balancing any over-reliance on social-respect in the courts' notion of dignity. However, in fact, retirement provisions are rarely imposed following meaningful individual consent. ${ }^{181}$ Many employees have no choice but to accept the terms on which employment is offered, and will have little or no opportunity to bargain or amend a retirement age specified in an employment contract. ${ }^{182}$ Further, most union members will have only 'diluted influence' over the terms of a collective agreement, limiting the meaningfulness of their consent. ${ }^{183} \mathrm{~A}$ retirement age is also unlikely to be a primary concern or consideration of many (particularly younger) employees at the time a contract is signed. In sum, consent to a retirement age is 'largely illusory' in most cases, ${ }^{184}$ undermining the argument that retirement ages should be seen as a negotiated private contractual arrangement. Thus, securing an autonomy-based view of dignity through a proportionality assessment grounded in individual consent is a flawed approach.

\footnotetext{
${ }^{180}$ Morley Gunderson, Banning Mandatory Retirement: Throwing out the Baby with the Bathwater (Backgrounder No 79, Toronto: CD Howe Institute, 2004) 6.

${ }^{181}$ For full discussion of this point, see Alysia Blackham, Extending Working Life for Older Workers: Age Discrimination Law, Policy and Practice (Oxford: Hart Publishing, 2016) ch 3.

${ }^{182}$ Connolly (n 131) 158.

183 ibid.

184 ibid.
} 
These issues are illuminated more fully in the UK case law. In Seldon 'there was no discussion' regarding the retention of a retirement age in the partnership deed ${ }^{185}$ and the clause had remained in the deed for 'as long as could be remembered'. ${ }^{186}$ The ET interpreted this as meaning that the retirement age was 'not controversial'. ${ }^{187}$ It could equally mean that the partners did not turn their minds to the provision, undermining the quality of Mr Seldon's consent. Indeed, the EAT noted: 'it was not clear when the compulsory retirement age had first been agreed; it always appears to have been part of the partnership deed' ${ }^{188}$ It is therefore difficult to argue that $\mathrm{Mr}$ Seldon consented meaningfully to the retirement age, though he did not object to it. Still, the original ET regarded the deed as a negotiated instrument:

the partners had agreed a compulsory retirement age between themselves. ... Here were parties of equal bargaining power agreeing between themselves what appeared to be a sensible and acceptable set of provisions. It is not akin to the position of an employee subject to a contract of employment who is perforce in an unequal relationship with his employer. ${ }^{189}$

This finding was endorsed by the EAT:

\footnotetext{
185 Seldon (n 121) [83].

186 ibid [79].

187 ibid [83].

${ }^{188}$ Seldon (n 107) [16].

189 ibid [27].
} 
We think it is a legitimate consideration that a rule of this kind was agreed by parties with equal bargaining power. ... [W]e think that the principle of justification which, after all, seeks to look at all the circumstances, should in principle take into account the fact that the partners must have perceived the rule to be in their collective interests. ${ }^{190}$

Consent was therefore a significant factor for the ET in upholding the proportionality of the retirement age in the partnership deed:

The consent of all the partners and the signing of the partnership deed in 2005 are not determinative but amount to strong factors to be taken into account in the determination of proportionality. ${ }^{191}$

This is supported by Willey, where the collaborative development of policies relating to the umpires' employment, ${ }^{192}$ and the involvement of the claimants in discussions of the retirement age, ${ }^{193}$ was strongly influential in the ET's reasoning. While the claimants in Willey 'did not have the same leverage as Mr Seldon' in negotiating their terms and conditions, they were 'far from being pawns'. ${ }^{194}$

While consent might be a superficially attractive means of distinguishing acceptable and unacceptable retirement ages, it is likely to be largely illusory in most

\footnotetext{
190 ibid [52]-[53].

${ }^{191}$ Seldon (n 121) [82].

192 Willey v England and Wales Cricket Board Ltd [2015] UKET 2201406/2014 (10 March 2015) [12].

193 ibid [16]-[18].

194 ibid [13].
} 
cases. We need, then, to look more broadly at how we can secure a more balanced form of dignity in the workplace, and how that might relate to mandatory retirement.

\section{Dignity at Work}

Dignity at work is an 'elusive' concept: ${ }^{195}$ there is a live debate regarding whether there is dignity in labour, such that 'meaningful work is essential for dignity', ${ }^{196}$ or whether paid work inevitably leads to a loss of autonomy and dignity. ${ }^{197}$ For Hodson, while dignity can be undermined by work, work is also a means of achieving dignity:

Dignity is the ability to establish a sense of self-worth and self-respect and to appreciate the respect of others. ... In the workplace, dignity is realized through countless small acts of resistance against abuse and an equally strong drive to take pride in one's daily work. ${ }^{198}$

Dignity at work, then, 'entails both defending one's inherent human rights and taking actions that are worthy of respect by oneself and others. ${ }^{\text {'199 }}$ This represents a fairly combative approach to dignity, where workers must create their own dignity through their actions and acts of resistance, in opposition to management. ${ }^{200}$ Hodson sees four challenges to dignity at work: mismanagement and abuse, overwork, limits

\footnotetext{
${ }^{195}$ Sharon C Bolton, 'Dignity in and at Work: Why It Matters' in Sharon C Bolton (ed), Dimensions of Dignity at Work (Amsterdam: Elsevier, 2007) 7.

${ }^{196}$ Randy Hodson, Dignity at Work (Cambridge: Cambridge University Press, 2001) 3.

${ }^{197}$ Bolton (n 195) 7. This reflects the Marxist idea of alienation through work.

${ }^{198}$ Hodson (n 196) 3.

199 ibid 4.

200 ibid 17.
} 
on autonomy, and contradictions of employee involvement. Conversely, Rayman identifies three pillars of dignity: livelihood, self-respect, and social responsibility. ${ }^{201}$ For Bolton, dignity has both objective and subjective dimensions: ${ }^{202}$ dignity in work is secured via interesting and meaningful work, autonomy, and social esteem and respect; ${ }^{203}$ dignity at work is achieved via equality of opportunity, voice, safety and health, security, and material rewards in terms and conditions. ${ }^{204}$ For very low skill jobs, Berg and Frost argue that dignity comes from pay, training and resources to do the job. ${ }^{205}$

Human resource management (HRM) offers at least the promise of respect and dignity at work. ${ }^{206}$ When implemented well, HRM can help both employers and employees to develop skills and capabilities, and to create rewarding work careers. HRM offers a means of facilitating individual voice and equality of opportunity at work, including through developmental processes, and can help employers and employees to collaboratively develop engaging, meaningful, respectful and autonomous work processes.

${ }^{201}$ Paula M Rayman, Beyond the Bottom Line: The Search for Dignity at Work (New York: St Martin's Press, 2001) 22.

202 Bolton (n 195) 8.

203 ibid. See also Sennett and Cobb, who argue that dignity at work is restricted by restricted freedom, which creates an 'existential wound': Richard Sennett and Jonathan Cobb, The Hidden Injuries of Class (New York: Knopf, 1973) 95-96.

204 Bolton (n 195) 8.

${ }^{205}$ Peter Berg and Ann C Frost, 'Dignity at Work for Low Wage, Low Skill Service Workers' (2005) 60 Relations industrielles 657.

${ }^{206}$ David Coats, 'Respect at Work: Just How Good Are British Workplaces?' in Sharon C Bolton (ed), Dimensions of Dignity at Work (Amsterdam: Elsevier, 2007) 54. 
That said, even the best HRM processes still see employees as means to organisational ends: ${ }^{207}$ what Islam describes as a 'reified' view of the workplace. ${ }^{208}$ McGaughey argues that this focus on humans as a means to an end harms productivity and human development. ${ }^{209}$ There is also a significant imbalance of power in most HRM processes: ${ }^{210}$ employers retain both power and managerial discretion in determining how processes are implemented. If anything, employer power is increasing in the modern world of work: Taylor describes a 'sea change in the political economy of work and employment, the adoption of a neo-liberal agenda, which has unambiguously strengthened managerial prerogative. ${ }^{211}$ This has led to an 'evolved form of performance management ... synonymous not with developmental HRM and agreed objectives but with a claustrophobically monitored experience of top-down

\footnotetext{
207 ibid.

${ }^{208}$ Islam (n 176) 327.

${ }^{209}$ Ewan McGaughey, A Human is not a Resource (Working Paper No. 497, Cambridge: Centre for Business Research, University of Cambridge, March 2018).

${ }^{210}$ Coats (n 206) 54.

${ }^{211}$ Philip Taylor, 'Performance Management and the New Workplace Tyranny - A Report for the Scottish Trades Union Congress' (no date) 80.
} 
target driven work.' ${ }^{212}$ A focus on 'hard' HRM, ${ }^{213}$ neoliberalism and managerialism ${ }^{214}$ has been associated with de-professionalisation and declining trust in professional workplaces. ${ }^{215}$ This may lead to job insecurity, employees being 'managed out', a

212 ibid.

${ }^{213}$ For Legge, 'hard' HRM sees employees as a resource, to be exploited for maximal return in alignment with business strategy: Karen Legge, Human Resource Management: Rhetorics and Realities (Management, Work and Organisations, Houndmills: Palgrave Macmillan, 2005) 105. By contrast, 'soft' HRM emphasises the 'human' element of HRM, and sees employees as valuable assets capable of development and worthy of trust. This 'soft' approach is described by Legge as 'Development Humanism': ibid 105-06. Organisations can adopt both soft and hard HRM simultaneously, but may emphasise one aspect or the other at different times: John Storey, Developments in the Management of Human Resources: An Analytical Review (Warwick Studies in Industrial Relations, Oxford: Blackwell, 1992) 26, ch 1 . A focus on the latter, soft HRM approach aligns with the approach advocated for by this article.

${ }^{214}$ Including through a push towards 'New Public Management' in the public service: see, for example, Christopher Hood, 'The "New Public Management" in the 1980s: Variations on a Theme' (1995) 20 Accounting, Organizations and Society 93.

${ }^{215}$ Michael Reed, 'Engineers of Human Souls, Faceless Technocrats, or Merchants of Morality?: Changing Professional Forms and Identities in the Face of the Neo-Liberal Challenge' in Ashly Pinnington and others (eds), Human Resource Management: Ethics and Employment (Oxford: Oxford University Press, 2007) 174-77. In the NHS, see Leo McCann and others, “'You Can't Do BothSomething Will Give": Limitations of the Targets Culture in Managing UK Health Care Workforces' (2015) 54 Human Resource Management 773, who argue for a return to professional norms and professional discretion; see further H Pownall, 'Neoliberalism, Austerity and the Health and Social Care Act 2012: The Coalition Government's Programme for the NHS and Its Implications for the Public Sector Workforce' (2013) 42 Industrial Law Journal 422. In education, see Anne Storey, 'From Performance Management to Capacity-Building: An Escape from the Cul de Sac?' (2004) 15 The Curriculum Journal 207. In further education, see Kim Mather and Roger Seifert, 'The Close Supervision of Further Education Lecturers: "You Have Been Weighed, Measured and Found Wanting" 
growth in occupational ill health and stress, ${ }^{216}$ and declining employment conditions. ${ }^{217}$ McGaughey similarly finds that a focus on HRM in countries such as the UK, USA and Japan is associated with lower productivity, higher unemployment, growing inequality, and lower growth. ${ }^{218}$ In this context, HRM could exacerbate Hodson's challenges to dignity at work, increasing the potential for mismanagement and abuse, overwork, limits on autonomy, and contradictions of employee involvement. ${ }^{219}$

If we were to remove retirement ages for older workers, then performance management and HRM '[take] on a new significance as the obvious transparent and non-discriminatory mechanism to terminate employment. ${ }^{220}$ While employees would no longer have to retire at a specific date, employers would choose the criteria for assessing and evaluating the performance of older workers, thereby having control over who stayed in employment. ${ }^{221}$ Further, many of the criteria used to evaluate employee performance are being increasingly standardised and unified, and fail to take into

(2014) 28 Work Employment Society 95. cf Kolsaker, who argues that managerialism in universities is not necessarily incompatible with professionalism: indeed, managerialism can enhance professionalism: Ailsa Kolsaker, 'Academic Professionalism in the Managerialist Era: A Study of English Universities' (2008) 33 Studies in Higher Education 513, 522.

${ }^{216}$ Taylor (n 211) 80.

${ }^{217}$ Ian Cunningham, 'Non-Profits and the "Hollowed out" State: The Transformation of Working Conditions through Personalizing Social Care Services during an Era of Austerity' (2016) 30 Work, Employment and Society 649, 662-64.

${ }^{218}$ McGaughey (n 209).

${ }^{219}$ Hodson (n 196) 17.

${ }^{220}$ Beck and Williams (n 157) 270.

${ }^{221}$ ibid 269. 
account individual differences. ${ }^{222}$ This could prove particularly challenging for older workers with diminished capacity. Employment is moving away from long-term, relational contracts, ${ }^{223}$ and is instead being set up to be impersonal and transactionbased.

Replacing mandatory retirement with 'hard' HRM or standardised performance management is unlikely to support any form of dignity at work. However, this is not the only form of HRM that is possible. A true commitment to achieving dignity in the workplace requires adopting more personalised and equitable management practices. This could be achieved through 'sustainable' HRM, grounded in respect, collaboration, and a desire for sustainable work careers. ${ }^{224}$ This reflects a focus on capacity-building, rather than on summative performance management, and a renewed emphasis on trust and professionalism. ${ }^{225}$ This form of performance management can both promote and enhance individual dignity if it acknowledges individual difference and needs. To do so, performance management must: be respectful, and achieve interactional justice through due process; $; 26$ be fair and just, in both processes and outcomes, to promote

\footnotetext{
${ }^{222}$ O’Neill (n 16) 124.

${ }^{223}$ White (n 157) 450-51.

${ }^{224}$ Peggy De Prins and others, 'Sustainable HRM: Bridging Theory and Practice through the 'Respect Openness Continuity (ROC)'-Model' (2014) 25 Management Revue 263. This approach aligns corporate social responsibility and HRM theory.

${ }^{225}$ In education, see Storey (n 215). This could be re-branded as a focus on 'human resource development': Norman Lucas and Derek Betts, 'The Incorporated College: Human Resource Development and Human Resource Management -contradictions and Options' (1996) 1 Research in Post-Compulsory Education 329.

${ }^{226}$ Elaine Farndale and others, 'High Commitment Performance Management: The Roles of Justice and Trust' (2011) 40 Personnel Review 5, 9.
} 
trust in the system; ${ }^{227}$ be applied equally to all employees; have legitimacy; ${ }^{228}$ be transparent and open, both in timing and the criteria for assessment; be delivered competently and sympathetically; give employees voice; address power imbalances, including through the provision of information and allowing individuals to have a supporter or union representative present; integrate both formative and summative elements, to ensure developmental aspects are addressed, including through the provision of training; and recognise employee autonomy, either by employee involvement in setting objectives, frequently discussing performance and offering feedback and providing some choice over pay and benefits, or by giving employees opportunities to develop through regular appraisal discussions which lead to new goals and opportunities. ${ }^{229}$ This represents a normative approach to HRM, and a call for better workplace practices that promote individual dignity.

In acknowledging individual difference and needs, a performance management system of this nature will encounter challenging questions regarding the extent to which it should acknowledge and accommodate individual age, ability, capacity and opportunity to perform. As noted in Part 3(c), age and capacity are not mutually predictive. However, where cases of age-related decline are detected, it is unclear how (if at all) work expectations should be moderated to accommodate the impact of ageing. One approach, modeled on disability law, would be to require reasonable accommodations for older workers with age-related incapacity or declining capacity. Thus, performance management systems could consider whether a lack of performance could be addressed by a reasonable workplace adjustment, including adjustments to

\footnotetext{
${ }^{227}$ Farndale and others (n 226).

${ }^{228}$ ibid 10.

229 ibid 8.
} 
work procedures or support structures; if it could not, or if the adjustment was not reasonable, then the employer would be able to initiate a process to end the employment relationship.

This approach, which acknowledges ageing and potential age-related incapacity as one aspect to consider in setting work expectations, is consistent with a 'work ability' approach to the ageing workforce, as adopted in Finland. Work ability is concerned with the physical, mental and social capacities of an individual to manage their role in the workplace, ${ }^{230}$ balancing personal factors with the demands of the job itself. ${ }^{231}$ It focuses on the match between work demands and individual capacity, and emphasises changes that can be made to both working conditions and individual competence to extend working lives. Work ability recognises the mutually supportive and mutually important roles and collaborative partnerships that may be formed between employers, employees and the social partners to improve and extend working lives. Thus, in contrast to the prevailing individualist approach to HRM seen in some workplaces, work ability offers the potential for a more collectivist approach to individual assessment, aligning both autonomy and social-respect.

Of course, 'work ability' approaches have been developed in a dramatically different national context to the UK, and in a country where collective negotiation and the social partners are an accepted and integral part of workplace culture. Arguing for a more humanistic approach to employment practices, let alone a humanistic approach that accommodates changing needs over the life course, is a radical political demand: as laid out by O'Neill,

\footnotetext{
${ }^{230}$ J Ilmarinen and K Tuomi, ‘Work Ability of Aging Workers' (1992) 18 Scandinavian Journal of Work, Environment \& Health 8, 8.

${ }^{231}$ J Ilmarinen, ‘Aging Workers’ (2001) 58 Occupational and Environmental Medicine 546, 548.
} 
The demand that we be treated as the particular persons we are on the job is a political demand for a 'maxim of employment' that acknowledges our desire and perhaps need to be treated more as the persons we are, and less impersonally. It is a demand that we must take seriously if we doubt that we are, even in the maturity of our faculties, merely consenting adults. ${ }^{232}$

This approach also stands in marked contrast to the 'age neutral' work structures adopted in many UK organisations, ${ }^{233}$ where age has 'little relevance' to decisionmaking. ${ }^{234}$ The need to reconcile a desire to treat people equally with acknowledgement of individual needs and differences is a central dilemma in UK equality law, ${ }^{235}$ which is also reflected in organisational practices. Thus, this approach to HRM reflects the call for renewed consideration of how organisations can adopt policies and processes that acknowledge and accommodate age, but do not condone age discrimination. ${ }^{236}$ It will therefore need to be adopted in conjunction with broader reforms to address age

\footnotetext{
${ }^{232}$ O’Neill (n 16) 125.

${ }^{233}$ Harris T Schrank and Joan M Waring, 'Older Workers: Ambivalence and Interventions' (1989) 503 Annals of the American Academy of Political and Social Science 113.

${ }^{234}$ Colin Duncan, 'The Dangers and Limitations of Equality Agendas as Means for Tackling Old-Age Prejudice' (2008) 28 Ageing \& Society 1133, 1138.

${ }^{235}$ Geraldine Healy and others, 'Inequalities, Intersectionality and Equality and Diversity Initiatives: The Conundrums and Challenges of Researching Equality, Inequalities and Diversity' in Geraldine Healy and others (eds), Equality, Inequalities and Diversity: Contemporary Challenges and Strategies (Management, Work and Organisations, Basingstoke: Palgrave Macmillan, 2010) 3.

${ }^{236}$ Blackham (n 181) ch 9.
} 
stereotypes and managerial biases against older workers, which is ultimately the objective of age equality law.

A humanistic approach to HRM also needs to take into account the diverse needs and circumstances of different organisations. For example, small and medium enterprises (SMEs) are more likely to adopt an informal approach to their workforce, and are unlikely to have formal HRM processes in place. While informal approaches to workforce management can co-exist with good practice, ${ }^{237}$ the European Commission has identified a lack of formal processes as a potential barrier for SMEs in adopting good equality practices. ${ }^{238}$ Other barriers often encountered by SMEs include a small workforce, high employment of family members, limited time and resources, other organisational priorities and economic insecurity. ${ }^{239}$ Thus, consideration needs to be given to how the positive aspects of a humanistic approach to HRM might be adopted within both formal and informal workplace structures, to accommodate the differing needs and practices of large and small firms.

More specifically, some employers encounter particular problems in implementing workforce management processes, and often rely on retirement ages as an alternative workforce management tool. This particularly affects judicial and quasi-

\footnotetext{
${ }^{237}$ Helen Barnes and others, 'An Ageing Workforce: The Employer's Perspective' (Brighton, 2009) vii. ${ }^{238}$ European Commission, 'Continuing the Diversity Journey: Business Practices, Perspectives and Benefits' (Luxembourg, October 2008) 18.

239 ibid.
} 
judicial roles, ${ }^{240}$ sports referees, ${ }^{241}$ and some universities, particularly those with a collegiate management structure, such as Oxford and Cambridge. ${ }^{242}$ Resistance to performance management in these workplaces may reflect a traditional view of performance management as being focused on deficiencies in performance, via summative or evaluative performance management. This ignores the developmental potential of HRM, which can (and should) involve targeted training and performance assistance $^{243}$ and a focus on formative or developmental goals. ${ }^{244}$ In practice, employers often revert to summative performance management, reinforcing employee

${ }^{240}$ This is reflected in the case law: see Lindsay v Department for Employment and Learning [2013] NIET 356/12 (19 December 2013), [2014] EqLR 180; John v Ministry of Justice [2014] UKET 3300891/2012 and 1700191/2013 (17 December 2014); Hampton v Lord Chancellor [2008] IRLR 258; White v Ministry of Justice [2014] UKET 2201298/2013 (25 November 2014); Engel v Transport and Environment Committee of London Councils [2013] UKET 2200472/2012 (26 April 2013).

${ }^{241}$ In the case law, see Martin v Professional Match Game Officials Ltd ('PMGOL') [2010] UKET 2802438/2009 (13 April 2010); Willey v England and Wales Cricket Board Ltd [2015] UKET 2201406/2014 (10 March 2015).

${ }^{242}$ See, for example, David E Guest and Michael Clinton, 'Human Resource Management and University Performance: Final Report' (London, November 2007) 6.

${ }^{243}$ Peggy G Koopman-Boyden and Lesley Macdonald, ‘Ageing, Work Performance and Managing Ageing Academics’ (2003) 25 J HE Policy and Management 29, 35.

${ }^{244}$ Geoff Sharrock, 'Performance Management and Cultural Difference in the Australian University' (1999) 36 Asia Pacific Journal of Human Resources 87, 87; Leanne Morris and others, 'Rhetoric and Reality: An Examination of Performance Management in Australian Universities' [2011] AIRAANZ 2011: Proceedings of the 25th Conference of the Association of Industrial Relations Academics of Australia and New Zealand 1, 3. 
resistance to HRM processes. ${ }^{245}$ The effective implementation of a humanistic approach to HRM, focused on developmental aspects of performance management, could address many of these concerns. ${ }^{246}$

While a humanistic approach to HRM is radical in the current national context, it also offers to deliver instrumental benefits, enhancing both organisational and individual interests, and is likely to lead to higher employee commitment, lower intentions to leave and higher productivity. ${ }^{247}$ Thus, a consistent, individualised approach to HRM that takes into account ageing is likely to yield longer-term benefits and rewards for both employees and employers. Given these benefits, it may well be possible - in time - to radically shift workplace culture and management perspectives to embrace a more humanistic approach to HRM. If successful, there is far more chance of upholding individual dignity using this approach, than through the use of mandatory retirement ages.

\section{CONCLUSION}

This article has illustrated the substantial limitations of using the prevailing conception of 'dignity' as a legitimate aim to justify age-based retirement practices. It advocates for a view of dignity that accommodates both individual autonomy and social-respect, while recognising that this could be achieved in practice through a variety of means.

\footnotetext{
${ }^{245}$ In the university context, see Alysia Blackham, 'Operating Without Mandatory Retirement: Comparative Organisational Strategies and Responses' (2016) 45 Industrial Law Journal 144. See also Morris and others (n 244).

${ }^{246}$ See, for example, Kolsaker (n 215) who argues that academics have come to see the benefits of managerialism in enhancing performance and professionalism.

${ }^{247}$ Farndale and others (n 226) 8.
} 
The article proposes a normative alternative to the use of retirement ages, advocating for a humanistic approach to employment practices and personalised performance management, to offer an alternative way to secure individual dignity in employment. This approach will not just benefit older workers: indeed, it offers significant advantages to all employees. Of course, this represents a radical (and perhaps idealistic) departure from current workplace practices and trends towards the standardisation of work and HRM. This article offers a different path, in the interests of securing the dignity of all at work. Thus, it serves to challenge prevailing employer practices in relation to equality and employment.

Reconsidering the notion of dignity embedded in case law would add significant symbolic value to the legal process, particularly given the dubious and potentially age discriminatory assumptions on which the notion relies. It prompts a deep reconsideration of one justification for retirement ages in the UK and EU. However, it is important to acknowledge that dignity is just one legitimate aim used to justify retirement ages, and recasting the notion of 'dignity' will not necessarily change legal precedent: most decisions relating to retirement ages are grounded in intergenerational fairness arguments, or fail on the proportionality assessment. Further, while reconsidering dignity can add value to the legal process, it will not make judicial decision-making any easier: as Feldman has argued, 'Giving weight to dignity adds a new value to the legal system which changes the way in which questions are asked and answered, allowing a wider range of interests to be taken into account, but not thereby making intractable moral and legal issues any easier.' ${ }^{248}$ In relation to equality law, where dignity is already a feature of legal reasoning, a new interpretation might help to

\footnotetext{
${ }^{248}$ David Feldman, 'Human Dignity as a Legal Value: Part 2' [2000] Public Law 61, 76.
} 
reframe complex issues, and cast new light on how we perceive older workers. However, it will not solve the complex balancing exercise that is inherent in any (re)consideration of retirement ages. Thus, we need to be more open and transparent about the values that are driving legal decision-making in this area, and the extent to which age stereotypes and stigma imbue the process. Adopting a more nuanced view of dignity is only the first step. 